\title{
EFFECT OF INCREASED OXYGEN CONCENTRATION ON NEW VESSEL GROWTH IN THE ADULT CORNEA*
}

BY

\author{
I. C. MICHAELSON, N. 'HERZ, AND D. KERTESZ \\ Haifa, Israel
}

Ir would appear that changes in the concentration of oxygen in the blood contribute to the disturbance of development of retinal capillaries which manifests itself as retrolental fibroplasia. An association between oxygen concentration and retinal capillary growth was suggested in anatomical studies by Michaelson (1948) and in physiological studies by. Campbell (1951). This associtaion has been further exemplified by experimental work with cats (Ashton, 1953) and with mice (Michaelson, 1954).

The following experiment was carried out to determine if an increased concentration of oxygen in the blood has any effect on vessel budding in the adult eye. The tissue chosen was the rabbit's cornea, and the lesion was a standard thermal lesion which provided that it is near enough to it produces an area of new vessel growth from the limbus (Campbell and Michaelson, 1949). Animals in which such a thermal lesion was produced were placed for 6 days in an incubator having an oxygen concentration of 50 per cent. Thereafter the extent of vascularization was measured. Similar lesions were made in rabbits which were maintained for a similar length of time in ordinary atmospheric conditions. At the end of the period a comparison was made between the vascularizations found in the two groups of animals.

\section{Material and Methods}

Six adult rabbits were kept in a wooden box into which oxygen was introduced at a constant rate. The resulting oxygen concentration was checked twice a day and the adjustments made to keep the concentration at a constant 50 per cent. level. Once a day the animals were taken out of the box and both corneae were given a standard thermal lesion by means of an electro-cautery at a distance-so far as could be judged-of about $2 \mathrm{~mm}$. from the limbus in the 12 o'clock meridian. On the 7th day the animals were killed and Indian ink was injected into the carotid arteries. Each cornea was removed and mounted on a microscopic slide, and the extent of the wound and of vessel growth were measured with the aid of a low-power microscope.

As a control measure a similar procedure was carried out in both eyes of four animals, except that these animals were not placed in an incubator.

\section{Results}

Incubated Animals.- The extent of vessel out-growth (height of growth) from the limbus is ind icated in Table $I$.

*Received for publication March 30, 1954. 
TABLE I

RABBITS KEPT FOR 6 DAYS IN 50 PER CENT. OXYGEN, CAUTERIZED DAILY, SIZE OF WOUND BETWEEN 1.0 AND 1.2 MM.

\begin{tabular}{c|c|c|c}
\hline Rabbit No. & Eye & $\begin{array}{c}\text { Distance of Wound from } \\
\text { Limbus (mm.) }\end{array}$ & Height of Vessel Growth (mm.) \\
\hline 189 & R & 2.4 & 0.0 \\
& L & 2.2 & 0.3 \\
\hline 190 & R & 2.1 & 0.3 \\
& L & 2.2 & 0.3 \\
\hline 191 & R & 2.3 & 0.4 \\
& L & 2.2 & 0.6 \\
\hline 192 & R & 2.2 & 0.6 \\
& L & 2.0 & 0.5 \\
\hline 193 & R & 1.8 & 0.6 \\
& L & 1.8 & 0.8 \\
\hline 194 & R & 1.5 & 1.1 \\
& L & 1.5 & 1.0 \\
\hline
\end{tabular}

It has been shown that, given a standard lesion, the extent of new vessel growth is greatly dependent on the distance of the wound from the limbus. In Rabbits 189-192 this distance is between 2.0 and $2.4 \mathrm{~mm}$.; in this group the average height of vessel growth is $0.4 \mathrm{~mm}$.

In Rabbits 193 and 194 the distance is between $1 \cdot 5-1 \cdot 8 \mathrm{~mm}$; in this group the average height of vessel growth is $0.9 \mathrm{~mm}$.

Animals not Incubated.-The extent of the vessel growth from the limbus in this group is indicated in Table II.

TABLE II

RABBITS KEPT IN AIR, CAUTERIZED DAILY FOR 6 DAYS, SIZE OF WOUND BETWEEN 1.0 AND 1.2 MM.

\begin{tabular}{c|c|c|c}
\hline Rabbit No. & Eye & $\begin{array}{c}\text { Distance of Wound from } \\
\text { Limbus (mm.) }\end{array}$ & Height of Vessel Growth (mm.) \\
\hline 195 & R & 2.2 & 0.4 \\
& L & 1.9 & 0.6 \\
\hline 196 & R & 1.9 & 0.6 \\
& L & 2.2 & 0.3 \\
\hline 197 & R & 1.6 & 0.7 \\
& L & 1.6 & 0.7 \\
\hline 198 & R & 1.6 & 0.9 \\
& L & 1.6 & 0.9 \\
\hline
\end{tabular}

In Rabbits 195-196 the distance from wound to limbus was between 1.9 and $2 \cdot 2 \mathrm{~mm}$; in these eyes the average height of vessel growth is $0.5 \mathrm{~mm}$. In Rabbits 197-198 the distance is $1.6 \mathrm{~mm}$.; in these eyes the average height of vessel growth is $0.8 \mathrm{~mm}$.

In comparing the extent of vascularization in the incubated and control animals, consideration must be given to the effect of variations in wound-limbal distance. It can then 
be said that in the circumstances of the experiment, no effect on new vessel growth in the cornea of the definitive rabbit eye was obtained by increasing the percentage of oxygen inhaled up to 50 per cent.

\section{Summary.}

(1) Of ten rabbits in which new vessel growth in both corneae had been produced by a standard lesion, six were kept in an incubator containing 50 per cent. oxygen for 6 days, while four used as controls were kept in ordinary air.

(2) The extent of the vessel growth in the twelve eyes belonging to the incubated animals and the eight eyes of the control animals was measured and compared.

(3) Increasing the concentration of oxygen in the air breathed to 50 per cent. did not affect the extent of new vessel growth in the adult cornea.

\section{REFERENCES}

ASHTON, N., WARD, B., and SerPell, G. (1953). British Journal of Ophthalmology, 37, 513. CAMPBeLL, F. W. (1951). Trans. ophthal. Soc. U.K., 71, 287.

and Michaelson, I. C. (1949). British Journal of Ophthalmology, 33, 248.

Michaelson, I. C. (1948). Trans. Ophthal. Soc. U.K., 68, 137.

(1954). British Journal of Ophthalmology, 38, 577. 